\title{
TEAM AND TEAMWORK IN THE FUNCTION OF EFFECTIVE MANAGEMENT
}

\author{
Sandra Stojadinović Jovanovići ${ }^{1}$ Ivana Bojovićc ${ }^{2}$, Boban Dašić ${ }^{3}$ \\ 12 Academy of Professional Studies Western Serbia, Department \\ Užice \\ ${ }^{3}$ Kosovo and Metohija Academy of Applied Studies, Department Peć- \\ Leposavić
}

Corresponding: sandrassj28@gmail.com ${ }^{1}$

Review article

Received: 18.03.2021; Accepted: 18.05.2021

\begin{abstract}
An unavoidable part of organizational life and management is teamwork. The goal of forming and using teams is to realize certain jobs and work tasks, to achieve or contribute to the achievement of certain results and thus the effective achievement of defined organizational goals. Only an effective team can contribute to the effectiveness of management. For these reasons, the subject of the paper is to consider the characteristics of the team and teamwork, the advantages and disadvantages of the use of teams and the effectiveness issue of the team itself. The aim of the paper is to point out the possibilities that the use of the team can provide, and also the obstacles it can bring, in order to recognize the ways of achieving and improving the effectiveness of the team.
\end{abstract}

Keywords: team, teamwork, management, effectiveness.

\section{Introduction}

Management is a process of working with the help and cooperation of other people in order to effectively achieve organizational goals with the efficient use of limited resources in a changing environment. [Kreitner, 1983] While efficiency means that the outputs or desired goals are achieved with minimal use of inputs or resources, effectiveness refers to the degree of achievement of goals that have been set. The more the desired goals are achieved the organization and its management are more efficient.

In addition to individual jobs and work tasks, a significant number of work tasks in the organization are 
performed through teamwork. An unavoidable part of organizational life and management is team i.e. team work. The goal of forming and using teams is to realize certain jobs and work tasks, to achieve or contribute to the realization of certain results and thus the effective realization of the set of organizational goals.

Only an effective team can contribute to the effectiveness of management. For these reasons the paper will consider the characteristics, advantages and disadvantages of the team and teamwork as well as the issue of the effectiveness of the team itself.

The first part of the paper defines the notion of team and explains the characteristics of teamwork, different types of teams that can be used as well as stages in team development. The second part of the paper points out the reasons for the team use and the numerous advantages that team, if used properly, can bring. At the same time, as teams face many obstacles, it is also pointed out to them as well as the fact that the expected advantages of using teamwork will not be realized automatically and that the disadvantages that teamwork can bring must be borne in mind. The third part of the paper deals with the issue of team effectiveness, that is the characteristics that make the team effective and the possibilities of achieving and improving teamwork and team effectiveness, concluding, among other things, when teams should be used and when they should not be used.

\section{Team and teamwork}

A team is made up of a group of individuals working together to achieve their goal. Peter G. Northouse defines the team as follows: "a team is a type of organizational group consisting of members who are interdependent, who have common goals and who must coordinate their activities to achieve these goals". [Northouse, 1997, 160] According to Halvorsen, a team is a set of individuals who are interdepen-dent in their tasks, share responsibility for outcomes and view themselves as a unit embedded in an institutional or organizational system that operates within the established boundaries of that system. [Halvorsen, 2013]

A team is a kind of group. Every team is a group, but not every group is a team. Each group does not become a team, but only one that develops certain characteristics, such as a high degree of identity, coherence, harmony and cooperation of members. The team is characterized by precisely stated goals, commitment to clear tasks and well-defined common goals. 
The widespread use of teams began in the United States in the 1980s, when industries such as automobiles and steel, trying to fight the growing Japanese competition, began to form the quality circles in which workers met weekly or monthly to discuss ways to improve quality. These teams helped companies to eliminate deficiencies and reduce reprocessing, but enthusiasm for them waned. One American study, which included 1,000 companies, found that $65 \%$ of $\mathrm{com}^{-}$ panies used such groups in 1986. According to Professor Ed Lawler "quality circles lose their appeal because they work in parallel with work processes, not within them." In other words, they are good for solving minor quality problems, but because they do not follow changes in the way they work, they cannot bring quantum leaps in productivity. [Dumaine, 1994]

Forming a team is a process that involves not only professional people, but also the selection of such individuals who are willing to work with each other in the team. Team management is based on respect for individuals, team members, and the division of labor between them. Members must see themselves as part of a team that take on part of the responsibility as well as part of the leadership, help other members and complement each other. Team implies cooperation of members and not competition as well as togetherness and teamwork.

An important feature of teamwork is that each team member is responsible for the results of the entire team rather than just their own results. The team determines the results it should achieve guided by the desired goals. For these purposes, it applies the decision-making process in which members declare, agree or disagree about the goals that have been set, steps or activities they need to take to achieve them as well as about the time (immediately or later) to take action. Action can include internal change, training, collaboration, but also action outside the team including networking with others and seeking support. The contribution of the team leader should be reflected in finding the ways to improve teamwork, addressing the issues the team is facing with and identifying the ways in which the team would like or could improve.

The types of teams that are formed and used are different. These are the most often types of teams: a) traditional working teams, that is teams with the lowest degree of autonomy in which two or more employees work together to achieve a common goal and report to managers; b) teams that encourage employee participation, that is teams with a slightly higher degree of 
Stojadinović Jovanović $S$. et al., Team and teamwork in the function of effective management

autonomy whose members provide management with advice and suggestions on specific issues but do not have the authority to make decisions; c) semi-autonomous working teams, that is teams which have the authority, although not complete, to make decisions and resolve problems related to basic issues of product production or service provision; d) self-governing teams, that is teams which manage core operations directly related to the production of products or the provision of services, without first obtaining the consent of management; and e) self-defined teams, that is teams which, in addition to the characteristics of self-governing teams, also control the way the team is organized, the execution of work tasks and team membership. [Williams, 2018, 176-178] The following types of teams can also be distinguished: interfunctional teams, which are composed of employees from different functional areas of the organization; virtual teams, which are composed of employees from different geographical areas or parts of the organization who use telecommunications and information technology in performing the organizational task; as well as project teams, which are formed in order to realize a certain project or task in a given period of time.

The most common are two broad types of teams: work teams, which include high-performance or selfmanagement teams, and specialpurpose problem-solving teams.

The initial types of teams from the 1980s, in which people took a few hours off each week to discuss problems, should not be seen as outdated, extinct forms, although their numbers have declined significantly. It should be borne in mind that they can increase productivity although they will not provide above-average incentives. Such incentives come precisely from selfgoverning or high - performance teams whose members are fully authorized to organize their work and make decisions.

Problem-solving teams have specific missions which can be broad (for example, to find out why customers do not like us) or narrow (for $\mathrm{ex}^{-}$ ample, to determine why a given product is constantly not working properly). Once the job is done, such teams are usually disbanded. One U.S. survey found that $91 \%$ of U.S. companies use problem - solving teams. On average, about $20 \%$ of a company's employees, at any given time, are on those teams. Although problem-solving teams are temporary teams, work teams used by about two-thirds of U.S. companies are usually permanent. Instead of solving specific problems, the work team works on a daily basis. [Dumaine, 1994] 
During their existence or lifetime teams go through certain phases. According to Tuckman [Tuckman \& Jansen, 1997] the stages of development are: formation, storm, standardization, performance and interruption. The formation phase primarily includes testing or identifying the boundaries of both interpersonal and task-related behavior establishing relationships with leaders and other group members. The second phase is characterized by conflict and polarization around interpersonal issues while, at the same time, members reacting emotionally to tasks. These behaviors serve as resistance to group influence and task demands and can be labeled as storms. In the third phase, that is the standardization phase, resistance is overcome, feeling and cohesiveness in the group are raised, new standards are developed and new roles are accepted. Personal opinions were expressed in the area of tasks. In the fourth phase, the performance phase, the roles become flexible and functional, and the group energy is taskoriented. Structural issues have been resolved and the structure can become a task support now. The last phase, the phase of interruption, means the dissolution or termination of roles, completion of tasks and reduction of dependence. According to some, this is a phase of mourning with respect to the loss that former participants feel. This phase can also be a stressful process, especially where a team break is unplanned.

\section{Advantages and disadvantages of teams}

When teams are successful, there is nothing like them that would contribute to productivity to such an extent. Thus, for example, some service companies in the United States, such as Federal Express and IDS, have increased productivity by up to $40 \%$ by introducing self-governing work teams. Boeing has used teams to reduce the number of engineering suspensions on its new passenger plane by more than half. According to the words of the then president of Boeing, Philip Condit: "Your competitiveness is your ability to make the most efficient use of people's skills and knowledge, and teams are the best way to do that". [Dumaine, 1994, 89]

The reasons for using teams are numerous. In addition to increasing productivity, if used properly, teams can raise morale, encourage innovation, increase customer satisfaction, product and service quality, job satisfaction and decisionmaking quality. [Williams, 2018, 173-174] For example, by forming a team and training it to meet certain customer needs, customer $\mathrm{sa}^{-}$ 
Stojadinović Jovanović $S$. et al., Team and teamwork in the function of effective management

tisfaction will also increase. Or, by leaving the responsibility for the quality of provided products and services to the team, whose bonus size will depend on the achieved performance, it is created the space for achieving higher quality of provided products and services. As teamwork provides an opportunity for employees to improve their skills, especially through training, as well as to express leadership skills in the position of team leader, it also increases employee satisfaction at work. Teamwork also increases the quality of decisionmaking process by using the advantages of group decision-making.

An important feature as well as an advantage of teams is that they can be quickly formed, reshaped and redesigned, without affecting other processes in the organization.

At the same time, the teams face a lot of obstacles. An explanation can be sought in this regarding the fact that the use of high-performance teams like the ones mentioned above that have achieved excellent results is not expanding as fast as might be expected. Thus a survey on the example of 1,000 companies has showed that $68 \%$ of companies use self-managed or highperformance teams. Although this finding gives the impression of great use by teams, research has also shown that only $10 \%$ of workers are present in such teams, [Dumaine, 1994] which is hardly a number that would lead to a crucial change.

The use of teams does not guarantee that the above mentioned expected reasons and advantages will be realized. Problems and shortcomings inherent in teamwork can primarily be those related to giving up teamwork, insufficient commitment in teamwork as well as shortcomings of group decisionmaking. [Williams, 2018, 174-175] Given that teamwork requires additional responsibility, effort and learning, some employees may request to be excluded from the team. Then, the bigger the team is, it is more probable that all team members will not be equally committed to fulfilling tasks and achieving team results, which will go hand in hand with the lazy people and discourage the most engaged team members. In addition, as group decision-making has its drawbacks, especially in terms of longer decision-making time and unanimity when bad decisions are made in order to avoid disagree-ments, they can also lead to additional shortcomings of teamwork.

Problems that arise in connection with the team and teamwork are also those that many companies often rush and form the wrong type of team for a given job or task. A 
particular problem is that teams are often left to fend for themselves without adequate support or involvement in other parts or changes in the organization. An additional problem is that teams are used where and when they are not really needed.

It often happens that a company because it is afraid to relinquish control, does not create the dynamic self-management team that is really needed and then wonders why its teams do not function or do not give good results. Teams are also often left to fend for themselves, sometimes in some sort of vacuum, with little or no training or support, no changes in the way they work, no introduction of new systems to help communication between teams and other changes in the organization. Dissatisfaction is created and members end up in infinitely long meetings trying to understand why they are in the team at all and what is expected of them. Precisely in line with the opinion of Paul Osterman, a professor of management at MIT's Sloan school: "When teams are introduced in combination with other changes in the organization, they work. When they are introduced as an isolated practice, they fail". [Dumaine, 1994, 90]

There is also a problem that teams are overused. Some companies will create teams where they don't really need them. What they don't realize is that employees, whether they're lonely individualists or creative types, aren't necessarily better in the team. Forcing them to sit in a team meeting, where they are waiting for a consensus to be reached can even diminish creativity.

When companies are in trouble, they often restructure into teams. However, putting people in teams does not solve problems by itself; if it is not done thoughtfully, it can cause even more problems. [Thompson, 2017]

For these reasons, it is crucial to analyze the job or task before the team is formed. It is necessary to consider whether the task really requires mutual interaction of people or the work can be done faster by one person. After all, the teams themselves need a lot of time and energy to form.

There are also a number of questions about paying teams. Thus, for example, the question arises whether to pay the team as a group, which, in turn, raises the question of whether the best team members will feel bad then? Or to pay team members according to individual performance, which then, in turn, raises the question of how teamwork will be encouraged in this way? Companies that gener- 
Stojadinović Jovanović $S$. et al., Team and teamwork in the function of effective management

ally make the best use of teams usually pay members individually, with a significant difference, but assuming they conduct teamwork, so sharing attitudes and the ability to get along well with others is a key issue in an individual's annual performance review.

The attitude "you will not succeed with teams if you do not change the attitude of people" is also related to teams and teamwork. This attitude stands, it is unavoidable and it must be kept in mind, but particularly with the fact that this attitude is changed primarily by the personal example of management and leaders and the attitude of management towards its staff i.e. its people.

\section{Team effectiveness}

Team effectiveness is the ability that a team has to achieve goals or tasks managed by authorized staff or organizations [Aubé \& Rousseau, 2011, 567]. Team effectiveness can also be defined as the ability of a group of people, usually with complementary skills, to work together to achieve the goals set by management, team members or team leaders. [Kellechi, 2020]

What kind of characteristics make the teams effective, i.e. which characteristics are a prerequisite for successful teamwork, is pointed out by Robbins and Coulter, among others. [Robbins \& Coutler, 2005] Also what makes the team effective is shown by Thompson, Hochwarter and Mathys. [Thompson et al., 1997] The relationship between workgroup characteristics and effectiveness in the context of the implications for designing effective workgroups is shown by Campion, Medsker, and Higgs. [Campion et al., 1993] Consequently, effective teams are characterized by the following features: a) clear goals; b) high competence of members with knowledge, skills and experience, with special importance of interpersonal skills without which, despite great expertise, bad effects can occur; c) mutual trust; d) commitment; e) good communication; f) negotiation skills; g) good leadership; h) internal and i) external support.

There are several models of team effectiveness, including the GRPI model, the model provided by Katzenbach and Smith, the T7 model, the models provided by LaFasto and Larson, Hackman and Lencioni, which show that there are several critical factors for achieving maximum team effectiveness. Accordingly, they help us understand what the best management techniques would be in order to get optimal performance from the teams.

The GRPI (Goals, Roles, Processes, Interpersonal relationships) team 
efficiency model highlights four team components that need to be effective. These are: 1) goals, in terms of well-defined goals and desired results with clearly stated priorities and expectations; 2) roles, in terms of well-defined responsibilities and acceptance of leaders; 3) processes, in terms of clear decision-making processes as well as working procedures; and 4) interpersonal relationships, in terms of good communication, trust and flexibility. [Beckhard, 1972] Because of its simplicity, this model is suitable when a team is being formed or when a problem related to the team is of unknown cause.

The team efficiency model of the Katzenbach and Smith highlights the three most significant results and goals of each team: the products of teamwork, the resulting performance and personal growth. In order to achieve these goals, productive teams must have three necessary components: 1) commitment, in the sense that teams are committed when they have a meaningful purpose, specific goals and a common approach to their work; 2) skills, in the sense that team members need problemsolving skills, technical skills to do the job and interpersonal skills to improve teamwork; and 3) responsibility, in the sense that team members must have personal and mutual responsibility. [Smith \& Katzenbach, 1993]

The T7 team effectiveness model was developed by Lombardo and Eichinger [Lombardo \& Eichinger, 1996] in order to define which factors affect team effectiveness. They identified five internal and two external factors, and as each, in English, started with "T", hence the name of the T7 model. The team's internal factors are: a) Thrust that is a common goal or objective; b) Trust or knowledge that the team has support; c) Talent or skills to perform the job; e) Teaming skills that is the ability to function as a team; e) Task skills that is the ability to perform tasks. The team's external factors are: a) the suitability of the team leader (Team leader fit), that is whether the leader cooperates well with the team and b) the support of the team from the organization (Team support from the organization), that is how the organization enables the team to work. In order for the team to have a high performance, all five internal factors must be present. However, no matter how complete the internal factors are, if leadership and organizational support are lacking, team effectiveness will be hampered. [Smith \& Katzenbach, 1993]

The team effectiveness model proposed by LaFasto and Larson, 
Stojadinović Jovanović $S$. et al., Team and teamwork in the function of effective management

called Five Dynamics of Teamwork and Collaboration, contains five layers or components that increase the probability of team effectiveness and they are: 1) a team member, in terms of his abilities and behavior; 2) team relations, in the sense that the right behavior in the team builds healthy working relations between its members; 3) problem solving in the team, in the sense that good team relations enable joint work on problem solving; 4) team leadership, in the sense that proper leadership increases team success; and 5) the organizational environment, in the sense that the right processes and company culture in the organization promote team commitment. [LaFasto \& Larson, 2001, 978]

The team effectiveness model proposed by Hackman highlights five conditions that must be met for team members in order to work together successfully. These are: 1) to be a real team and not a nominal team. Effective teams have a boundary that separates who is the part of the team, members are interdependent, and membership is usually stable; 2) have a clear direction towards which everyone is directed. This means setting goals that are clear, challenging and $\mathrm{mo}^{-}$ tivating enough for team members to strive for together; 3) have a structure that allows teamwork. The structure of the team, its be- havior and the way it organizes and works on its tasks should enable team work, and not hinder it; 4) have support in the organization that enables the team to work efficiently. This means that the team receives adequate resources, rewards, information, cooperation and support needed to do its job; and 5) providing training, professional training and team leadership. Effective teams are those who have access to a mentor or coach who can help them with the issues they dealing with. [Hackman, 2002] The team effectiveness model set by Lencioni is based on the causes of dysfunctions, conflicts and political maneuvers in the work team. Knowing team dysfunction means understanding how to cure it. These five dysfunctions are: 1) lack of trust. If team members are afraid of being vulnerable or afraid to ask for help then they will not turn to their teammates for help; 2) fear of conflict. If everyone tried to preserve peace at all costs, there would be no dynamic conflicts that would result in productive ideas; 3) lack of commitment. If people are not committed to their job or team, they will not follow their decisions or deadlines; 4) avoidance of liability. This is another flaw in the fear of conflict where people do not want to shift responsibility for their work to others; 5) neglect of results. If personal goals become more impor- 
tant than team success, no one will monitor and optimize team work. Lencioni's model implies that each dysfunction is solved one by one from the bottom upwards, i.e. from the last to the first. [Lencioni, 2005]

Team effectiveness models help us to identify shortcomings that hinder the team from collaboration and creation of successful results. Understanding a team's effectiveness model helps determine which of the models would be the best to optimize a given team by highlighting what works and what needs to be improved.

Team leaders should be aware of the unique dynamics and relationships in their teams and create space to consistently improve team performance. When asked what makes some teams better than others - the answer would primarily be that it is less about who is in the team and more about how and how well they work together.

It is important to keep in mind that the way team members work together determines the success of a team much more than the strength of individual team members.

Therefore, leaders who focus on creation of a model of effective teamwork encourage the work of all involved, and thus the success of their organizations.
High-performance teams are a unique blend of individual perspectives, group dynamics and organizational support.

Forming teams is best suited for difficult, complex and important tasks. These types of tasks are often beyond the skills and abilities of any individual. However, forming a team that will perform such and other tasks does not guarantee success. Instead the proper implementation of teams is positively associated with both member satisfaction and increased effectiveness. Organizations that want to achieve the benefits that teams bring must carefully consider how teams are built and implemented.

Teams are often created without providing any training to members to develop the skills needed to work well in a team environment. How ever, training can greatly benefit team effectiveness. [Kozlowski \& Ilgen, 2006]

Training of the team members is a critical aspect, as teamwork can be cognitively and interpersonally demanding. Even when a team consists of talented individuals, these individuals must learn to coordinate their actions and develop functional interpersonal interactions. [Forsyth, 2006]

Teams are more likely to be successful when the organization gives 
Stojadinović Jovanović $S$. et al., Team and teamwork in the function of effective management

them full support. O'Reilly and Pfeffer have shown that, by applying a new team structure in which management and company are more supportive to the union workforce, it can be created one of the most productive plants, in this case in the automotive industry, producing high quality cars. [O'Reilly \& Pfeffer, 2000]

The chances of successful teams can increase if it is approached carefully to the following: 1) setting team goals and priorities; 2) selection of team members; 3) training; 4) rewarding; 5) communication in the team; 6) team leadership; and 7) team conflict. [Williams, 2018] Amason, Hochwarter and Thompson [Amason et al., 1995, 20] as well as Amason [Amason, 1996] have shown that conflict management is an important aspect of improving teamwork.

One of the important factors is the choice of team members. A careful approach to the selection of team members increases the chances of the team to be effective. Choosing team members, although it may seem so, is not an easy task at all. The management professor Edward Lawler says that: "people are very naive about how easy it is to create a team. Teams are the Ferraris of work design. They are high performance but high maintenance and expensive." [Dumaine, 1994, 91]
According to Williams [Williams, 2018] it is almost impossible to have an effective work team without a careful selection of people who are capable of teamwork or to work in a particular team. Šušnjar and Zimanji [Šušnjar \& Zimanji, 2005] agree that assembling a team is a process that implies not only a combination of professional people, but also the selection of such individuals who are ready to work with each other within the team according to the previously stated principles. The relationship and influence of team member structure on team performance was also pointed out by Neuman, Wagner and Christiansen. [Neuman et al., 1999]

A team member is also a leader whose change can greatly affect the effectiveness of the team. The fact that change in the field of leadership, for example rotation of leaders, has effects on the functioning and effectiveness of the team has been shown by Erez, Lepine and Elms. [Erez et al., 2002]

It is often thought that a strong, powerful and charismatic leader is needed for teams to function effectively. However, leaders who control all the details, manage all the key relationships in the team, have all the good ideas and use the team to carry out their vision are usually overworked and underproductive. [Thompson, 2017] 
What teams need is a transformational leader whose behavior is characterized by the following: [Bass \& Riggio, 2006]

- idealized influence or the ability to involve people in their own actions which means that people like the way they work, they like the way they treat people and they like the approach to problems. Idealized influence is very much related to the charisma of the leader;

- inspirational motivation or the ability to inspire others with their vision which means that, with their inspirational motivation, they act on their followers to achieve things that they did not believe was possible;

- intellectual stimulation or the ability to encourage others to be creative and challenge the prejudices they have. This behavior allows the leader to use creativity as a competitive advantage;

- individual consideration or the ability to truly know those they want to lead. This behavior allows leaders to understand and use the full potential of others.

In addition to all the above, on the way to overcoming team shortcomings and improving teamwork and team effectiveness, the following is important:
- Use the right team for the right job,

- Create a hierarchy of teams,

- You can't have teams without trust and

- Tackle the people issues head-on. [Dumaine, 1994]

A common mistake among managers is to think that a team will be a team by itself. Also it is a common mistake to approach the formation of a team as if there is only one type of team or one tool for all jobs and tasks. It is necessary to use certain types of teams depending on the need, for example: problem solving teams, product development teams, self-management teams, virtual teams and other types of teams depending on the need of the job or the nature of the task.

In addition, teams will not meet expectations if companies do not force them to work together with other teams. If teams are not given a proper place in the organization, the whole organization can stagnate.

An important feature of teams and successful teamwork is the mutual trust of team members. Therefore its absence certainly leads to a lack of team effectiveness.

Although the right types of teams have been formed, an atmosphere 
Stojadinović Jovanović $S$. et al., Team and teamwork in the function of effective management

of trust has been built and the organizational structure has changed, it can also happen that the teams are still not doing well. The key reason then lies in the neglect of our staff and their problems, that is that we do not deal with our people. That is why it is important to get people to start cooperating and train managers and workers to behave openly and honestly towards other team members. It is also important to keep in mind the fact that, no matter how much they are trained, the most team members accept a given behavior by looking at exactly how management works.

Given all the above, the characteristics, advantages and disadvantages of using teams and the inevitable need to establish a useful and successful team and achieve effective teamwork, it is also important to state in which situations teams should be used and in which they should not. Teams should be used: when there is a clear, convincing reason or purpose for it; when work cannot be done if people do not work together; when rewards for teamwork and team performance can be provided; and when there are quite enough resources available. Teams should not be used: when there is no clear, convincing reason or purpose for it; when people can do the job on their own; when awards are given to individuals for individual results; and when the necessary resources are not available. [Williams, 2018, 176 ]

\section{Conclusion}

An integral part of organizational life and management is team and teamwork. The benefits of using teams are numerous, including increased productivity, customer satisfaction, product and service quality, job satisfaction and decisionmaking quality. The expected advantages will not be achieved automatically because the teams face a lot of obstacles. Significant shortcomings may occur which are inherent in teamwork such as giving up teamwork, insufficient commitment to teamwork and shortcomings of group decisionmaking. In addition, the wrong type of team is often formed to do a given job, teams are often left to themselves without adequate support or involvement in other parts or changes in the organization, and are often used where and when they are not really needed. Forming a team does not solve problems by itself.

In order to contribute to the effectiveness of management the team itself must be effective, that is to contribute as much as possible to the achievement of defined goals. The characteristics that make team 
effective are clear goals, high competence of members who have knowledge, skills and experience, with special importance of interpersonal skills, mutual trust, commitment, good communication, negotiation skills, good leadership, internal and external support.

Team effectiveness models show that there are several critical factors for achieving maximum team effectiveness, help in identifying gaps that hinder the team from collaborating and achieving successful results and point to appropriate team management techniques to achieve optimal performances.

Team leaders should be aware of the unique dynamics and relationships in their teams and create space to consistently improve team performance.

It is important to keep in mind that it is less about who is in the team and more about how and how well team members work together, that is the way team members work together determines the success of the team much more than the strength of individual team members.

High-performance teams are a unique blend of individual perspectives, group dynamics and organizational support.

Consequently the basis for establishing an effective team and then increasing its effectiveness should be sought in a careful approach to every step of team formation and use, starting from a careful approach to setting team goals and priorities, selecting team members and training to a careful approach to rewarding team leadership and managing team conflict.

In addition, in order to overcome team shortcomings, improve teamwork and team effectiveness, it is important to form and use the right team for the right job, establish a hierarchy of teams, build trust among team members and deal with the problems of the members. It is also important to know in which situations to use teams and in which not.

\section{Reference}

Amason, A.C., (1996). Distinguishing the Effects of Functional and Dysfunctional Conflict on Strategic Decision Making: Resolving a Paradox for Top Management Teams, Academy of Management Journal 39, no. 1: 123-148.

Amason, A.C., Hochwarter, W.A. \& Thompson, K.R. (1995). Conflict: An Important Dimension in Successful Management Teams, Organizational Dynamics 24.

Aubé, C. \& Rousseau, V. (2011). Interpersonal aggression and team effectiveness: The mediat- 
Stojadinović Jovanović $S$. et al., Team and teamwork in the function of effective management

ing role of team goal commitment, Journal of Occupational and Organizational Psychology. 84(3).

doi:10.1348/096317910X492568

Bass, B.M. \& Riggio, R.E. (2006). Transformational Leadership.

New York.

https://doi.org/10.4324/9781410 617095

Beckhard, R., (1972). Optimizing Team Building Efforts, Journal of Contemporary Business, 2327.

Campion, M.A., Medsker, G.J. \& Higgs, A.C., (1993). Relations between Work Group Characteristics and Effectiveness: Implications for Designing Effective Work Groups, Personnel Psychology 46, no. 4, 823-850.

Dumaine, B., (1994). The Trouble with Teams, Fortune 130:5: 8692.

Erez, A., Lepine, J. \& Elms, H., (2002). Effects of Rotated Leadership and Peer Evaluation on the Functioning and Effectiveness of Self-Managed Teams: A Quasi-Experiment, Personal Psychology 55, issue 4: 929-948.

Forsyth, D.R., (2006). Teams. In Forsyth, D.R., Group Dynamics (5th Ed.) (P. 351-377). Belmont: CA, Wadsworth, Cengage Learning.
Hackman, J.R., (2002). Leading Teams: Setting the Stage for Great Performances, Harvard Business Review.

Halvorsen, K., (2013). Team decision making in the workplace: A systematic review of discourse analytic studies. Journal of Applied Linguistics and Profes ${ }^{-}$ sional Practice. 7(3): 273-296. doi:10.1558/japl.v7i3.273

Kelechi, U., (2020), 6 Different Team Effectiveness Models to Understand Your Team Better, July 30, 2020, https://www.wrike.com/blog/6different-team-effectivenessmodels/

Kozlowski, S.W.J. \& Ilgen, D.R., (2006). Enhancing the effectiveness of work groups and teams. Psychological Science in the Public Interest. 7(3): 77-124. CiteSeerX10.1.1.115.953. doi:10.1111/j.15291006.2006.00030.

Kreitner, R., (1983). Management, 2nd ed., Boston, Houghton Mifflin Company.

LaFasto, F.M.J. \& Larson, C., (2001), When Teams Work Best: 6,000 Team Members and Leaders Tell What it Takes to Succeed, SAGE Publications, Inc; 1 edition. ISBN-10: 0761923667, ISBN-13: 978-0761923664 
Lencioni, P., (2005). The Five Dysfunctions of a Team, Wiley, John \& Sons, Incorporated.

Lombardo, Michael M; Eichinger, Robert W (1996). The Career Architect Development Planner (1st ed.). Minneapolis: Lominger. ISBN 0-9655712-1-1.

Neuman, G.A., Wagner, S.H., \& Christiansen, N.D., (1999). The Relationship between WorkTeam Personality Composition and the Job Performanse of Teams, Group\&Organization Management 24, no. 1: 28-45.

Northouse, P. G., (1997). Leadership: theory and practice, Sage Publications.

ISBN 9780803957688.

O'Reilly, Ch.A., \& Pfeffer, J., (2000). Hidden Value: How Great Companies Achieve EXtraordinary Results with Ordinary People. Boston, Massachusetts: Harvard Business School Press. pp. 175-200. ISBN 9780875848983.

\footnotetext{
${ }^{1}$ https://orcid.org/ 0000-0003-1383-0225

2 https://orcid.org/ 0000-0001-7260-0927

3 https://orcid.org/ 0000-0003-1980-8707
}

Robbins, S.P. \& Coulter, M., (2005). Menadžment, 8. izdanje, Data Status.

Smith D.K. \& Katzenbach, J., (1993). The Wisdom of Teams, Boston, Harvard Business Review Press.

Šušnjar, G.̌̌s. \& Zimanji, V., (2005). Menadžment ljudskih resursa, Univerzitet u Novom Sadu,

Tuckman, B.W. \& Jensen, M.A.C., (1977). Stages of Small-Group Development Revisited, Group \& Organization Studies, 2(4), 419-427.

Thompson, L., (2017). Making the team: a guide for managers (Sixth ed.). ISBN 978-0134484204

Thompson, K.R., Hochwarter, W.A., \& Mathys, N.J., (1997) "Stretch Targets: What Makes Them Effective?", Academy of Management Executive 11, no. 3: 48-60.

Williams, Ch., (2018), MGMT: Principles of Management, Boston, Cengage Learning. 


\title{
TIM I TIMSKI RAD U FUNKCIJI EFIKASNOG UPRAVLJANJA
}

\author{
Sandra Stojadinović Jovanović ${ }^{1}$, Ivana Bojović ${ }^{2}$, Boban Dašić ${ }^{3}$ \\ 12 Akademija strukovnih studija Zapadna Srbija, odsek Užice \\ ${ }^{3}$ Akademija strukovnih studija Kosovsko Metohijska, odsek Peć- \\ Leposavić
}

Korespondencija: sandrassj28@gmail.com ${ }^{1}$

Rezime: Nezaobilazan deo organizacijskog života i menadžmenta čini tim odnosno timski rad. Cilj formiranja i korišćenja timova jeste da realizuju pojedine poslove i radne zadatke, ostvare ili doprinesu ostvarenju pojedinih rezultata i time efektivnom ostvarenju postavljenih organizacionih ciljeva. Samo efektivan tim može doprineti efektivnosti menadžmenta. Iz tih razloga predmet rada jeste razmatranje karakteristika tima i timskog rada, prednosti i nedostataka korišćenja timova i pitanja efektivnosti samog tima. Cilj rada jeste ukazivanje na mogućnosti koje korišćenje tima pruža, ali i prepreka koje nosi, radi prepoznavanja načina ostvarivanja i unapređenja efektivnosti tima.

Ključne reči: tim, timski rad, menadžment, efektivnost. 